\title{
Agranulocytosis during Tuberculosis Therapy - Cautious Use Of Allopurinol
}

\author{
Sheng Hsiang $\mathrm{Ma}^{1}$ and Chun Hsing Liao*2 \\ ${ }^{1}$ Department of medicine, National Yang-Ming University, Taiwan \\ ${ }^{2}$ Department of Internal Medicine, Far Eastern Memorial Hospital, Taiwan
}

Received: May 18, 2018; Published: May 23, 2018

*Corresponding author: Chun Hsing Liao, Department of Internal Medicine, Section of Infectious Disease, Far Eastern Memorial Hospital, 21 Nan-Ya South Road, Section 2, Dist. Banquiao, New Taipei City, Taiwan

\section{Case Report}

A 61-year-old man had a past history of type II diabetes mellitus, stage four chronic kidney disease, coronary artery disease and congestive heart failure under medical treatment. During September 2012, he was admitted due to general weakness, and was later diagnosed with pulmonary and peritoneal tuberculosis. Rifampin, isoniazid, ethambutol and pyrazinamide were prescribed as standard treatment. The patient's serum creatinine was $3.6 \mathrm{mg} / \mathrm{dL}$ with hyperuricemia $(9.8 \mathrm{mg} / \mathrm{dL}$ ). Considering his hyperuricemia and history of gout, allopurinol $100 \mathrm{mg} /$ day was also initiated.

However, fever with chills developed two weeks after discharge. He visited emergency department on October $13^{\text {th }}$. Examination revealed fever $\left(38.8^{\circ} \mathrm{C}\right)$, tachycardia $(129 / \mathrm{min})$, tachypnea $(20 / \mathrm{min})$, oral ulcer, icteric sclera, bilateral lower legs edema and diffuse morbilliform skin rash. Anemia (hemoglobin $4.7 \mathrm{mg} / \mathrm{dL}$ ), thrombocytopenia $(100000 / \mu \mathrm{L})$, leukopenia $(1800 / \mu \mathrm{L})$, and neutropenia (5\%) were found without eosinophilia (0\%). Laboratory data revealed elevated creatinine $(4.4 \mathrm{mg} / \mathrm{dL}), \mathrm{LDH}(330 \mathrm{IU} / \mathrm{L})$ and total bilirubin level $(2.6 \mathrm{mg} / \mathrm{dL})$, while liver enzyme levels were within normal range. Adverse drug reaction was considered and all prior medications were discontinued. Cefepime and levofloxacin were prescribed for his neutropenic fever, accompanied with em pirical fluconazole. Besides, filagrastim was also initiated. A bone marrow biopsy revealed normal cellularity and no decrease of precursor cells. On October 18th, leukopenia $(1900 / \mu \mathrm{L})$ and agranulocytosis $(0.0 \%)$ were found, with persistent fever and multiple organ dysfunctions. One set of blood culture showed yeast growth, and fluconazole was shifted to micafungin. On October $23 \mathrm{rd}$, drop of blood pressure, dyspnea and progressive drowsiness were noted. The patient and his family refused further intervention and the patient expired this evening due to Candida tropicalis fungemia with septic shock after agranulocytosis.

Agranulocytosis, defined as neutrophil count under 0.5x109/L, is mostly induced by drugs $[1,2]$. Causative agent in this patient is difficult to be determined, because both anti-tuberculosis drugs and allopurinol had been reported (Table 1) [3]. We suggested allopurinol be the culprit of agranulocytosis in this case. First, previous research showed that allopurinol use within one week carried a relative risk of 6,7 to development of agranulocytosis compared to no use, but anti-tuberculosis agents had no similar analysis [2]. Second, the dose of allopurinol was not titrated slowly according to his renal function, increasing the possibility of allopurinol hypersensitivity [4]. Third, his liver enzyme levels were not elevated, which was the most common adverse effect of anti-tuberculosis drugs.

Table 1: Summary of agranulocytosis caused by allopurinol or anti-tuberculosis agents.

\begin{tabular}{|c|c|c|c|c|c|c|c|}
\hline Title, author, publication year & Age & Sex & Drugs & Culprits & WBC & Neut(\%) & Outcome \\
\hline Allopurinol and agranulocytosis, Wilkinson, 1977 & 50 & $\mathrm{~F}$ & A & A & NA & 0 & dead \\
\hline Aplastic agranulocytosis after allopurinol therapy, Greenberg, 1972 & 62 & $\mathrm{~F}$ & A & A & 500 & NA & dead \\
\hline Agranulocytosis: an adverse effect of allopurinol treatment, Elisa, 2011 & 90 & M & A & A & 300 & 10 & alive \\
\hline Agranulocytosis during Isoniazid therapy, Varadi, 1953 & 20 & M & $\mathrm{H} / \mathrm{P} / \mathrm{S}$ & $\mathrm{H}$ & 4900 & 1 & alive \\
\hline Agraulocytosis caused by isonicotinic acid acid hydrazide, Adar, 1953 & 14 & $\mathrm{~F}$ & $\mathrm{H} / \mathrm{P}$ & $\mathrm{H}$ & 1600 & 0 & alive \\
\hline $\begin{array}{l}\text { Agranulocytic reaction in a woman with pulmonary tuberculosis, Spesivtsev, } \\
\qquad 1968\end{array}$ & 18 & $\mathrm{~F}$ & $\begin{array}{l}\mathrm{H} / \mathrm{S} / \\
\text { etoxyd }\end{array}$ & $\begin{array}{l}\mathrm{H} / \mathrm{S} / \\
\text { etoxyd }\end{array}$ & 3300 & 1 & alive \\
\hline Agrnulocytosis following isoniazid- a case report, Sharma, 1979 & 23 & M & $\mathrm{H}$ & $\mathrm{H}$ & 2300 & 10 & alive \\
\hline
\end{tabular}




\begin{tabular}{|c|c|c|c|c|c|c|c|}
\hline $\begin{array}{l}2 \text { cases of neutropenia during treatment of pulmonary tuberculosis, We- } \\
\text { slaew, } 1969\end{array}$ & 21 & $\mathrm{~F}$ & $\mathrm{H} / \mathrm{S} / \mathrm{P} / \mathrm{E}$ & $\mathrm{H} / \mathrm{S} / \mathrm{P} / \mathrm{E}$ & 4000 & 2 & alive \\
\hline $\begin{array}{l}\text { Acute agranulocytosis in a pregnant woman treated for pulmonary tubercu- } \\
\qquad \text { losis, Livandovskii, } 1969\end{array}$ & 23 & $\mathrm{~F}$ & $\begin{array}{l}\mathrm{H} / \mathrm{S} / \\
\text { etoxyd }\end{array}$ & $\begin{array}{l}\mathrm{H} / \mathrm{S} / \\
\text { etoxyd }\end{array}$ & 700 & 0 & alive \\
\hline Anaphylatic bone marrow crisis following isoniazid therapy, Horvath, 1970 & 51 & $\mathrm{~F}$ & $\mathrm{H}$ & $\mathrm{H}$ & 2400 & $0 \cdot 5$ & alive \\
\hline Agranulocytosis due to INH toxicity, Ahuja, 1970 & 50 & $\mathrm{~F}$ & $\mathrm{H} / \mathrm{S}$ & $\mathrm{H}$ & 3600 & 0 & alive \\
\hline Agranulocytosis following isoniazid, Mechrotra, 1973 & 37 & $\mathrm{M}$ & $\mathrm{H} / \mathrm{S} /$ & $\mathrm{H}$ & 2000 & 6 & alive \\
\hline \multicolumn{8}{|l|}{$\begin{array}{l}\text { Agranulocytosis due to anti-tuberculosis drugs including Isoniazid and } \\
\text { Rifampicin, Shishido, } 2003\end{array}$} \\
\hline Case1 & 51 & $\mathrm{~F}$ & $\begin{array}{l}\mathrm{H} / \mathrm{R} / \mathrm{E} / \\
\mathrm{Z} / \mathrm{A}\end{array}$ & $\mathrm{R}$ & 1300 & 1 & alive \\
\hline Case2 & 66 & M & $\mathrm{H} / \mathrm{R} / \mathrm{E}$ & $\mathrm{R}$ & 2300 & 2 & alive \\
\hline Case3 & 60 & $\mathrm{~F}$ & $\begin{array}{l}\mathrm{H} / \mathrm{R} / \mathrm{E} / \\
\mathrm{Z} / \mathrm{A}\end{array}$ & $\mathrm{Z}$ ? & 900 & 1 & alive \\
\hline Case4 & 60 & M & $\mathrm{H} / \mathrm{R} / \mathrm{S}$ & $\mathrm{H} / \mathrm{R} / \mathrm{S}$ & 800 & 0 & dead \\
\hline $\begin{array}{l}\text { A case of agrnulocytosis caused by rifampicin during treatment of tubercu- } \\
\text { lous lymphadenitis in a chronic renal failure patient, Squiyama, } 2012\end{array}$ & 52 & $\mathrm{~F}$ & $\mathrm{H} / \mathrm{R} / \mathrm{E} / \mathrm{Z}$ & $\mathrm{R}$ & 2100 & 5 & alive \\
\hline Our case & 61 & M & $\begin{array}{l}\mathrm{H} / \mathrm{R} / \mathrm{E} / \\
\mathrm{Z} / \mathrm{A}\end{array}$ & A & 1900 & 0 & dead \\
\hline
\end{tabular}

A: Allopurinol; H: Isoniazid; R: Rifampin, Z: Pyrazinamide, S: Streptomycin; E: Ethambutol, P: Para-aminosalitilic acid; NA: not available

Allopurinol induced agranulocytosis was reported mainly among patients with leukemia receiving chemotherapy $[1,3,4]$. On the contrary, there were fewer reports of agranulocytosis caused by allopurinol among patients receiving tuberculosis treatment. In the report of Shishido, they reported four cases of agranulocytosis and attributed the causes to anti-tuberculosis medications [2]. However, two out of the four patients also used allopurinol, for which allopurinol related agranulocytosis cannot be completely ruled out. As allopurinol can lead to lethal hypersensitivity and agranulocytosis, its use should be assessed carefully. During treatment for tuberculosis, pyrazinamide can cause and aggravate hyperuricemia, but mostly asymptomatic. As a result, prophylactic use of allopurinol is not suggested. Once needed, genetic testing (HLA-B5801) before usage should be considered [5].

Patients with agranulocytosis are at risk of severe infection even aggressively treated. Discontinuation of the possible medication is the single most important intervention, but it is sometimes difficult to identify the causative agent. G-CSF can be used, but not all studies indicated its benefits. Broad spectrum antibacterial agents should be initiated for patients with sepsis, but the role of empirical antifungal agent is controversial. For this patient, we used strong antimicrobial agents empirically, while he still developed breakthrough candidemia and died. In conclusion, prophylactic use of allopurinol for hyperuricemia among patients receiving tuberculosis treatment should be avoided.

\section{Contributors}

SH and CL reviewed the case and literature together. SH prepared the manuscript. All authors contributed to drafting the manuscript and approved the final version. CL Liao had full access to all the data, and had final responsibility for the decision to submit for publication.

\section{References}

1. Andersohn F, Konzen C, Garbe E (2007) Systematic review: agranulocytosis induced by nonchemotherapy drugs. Ann Intern Med 146: 657-665.

2. Shishido Y, Nagayama N, Masuda K, Kurashima A, Komatsu H, et al. (2003) Agranulocytosis due to anti-tuberculosis drugs including isoniazid (INH) and rifampicin (RFP)-a report of four cases and review of the literature. Kekkaku 78: 683-689.

3. Kaufman DW, Kelly JP, Jurgelon JM, Leaverton P, Levy M, et al. (1996) Drugs in the aetiology of agranulocytosis and aplastic anaemia. Eur J Haematol Suppl 60: 23-30.

4. Hande KR, Noone RM, Stone WJ (1984) Severe allopurinol toxicity. Description and guidelines for prevention in patients with renal insufficiency. Am J Med 76: 47-56.

5. Hung SI, Chung WH, Liou LB, Chen CH, Fann CS, et al. (2005) HLA-B*5801 allele as a genetic marker for severe cutaneous adverse reactions caused by allopurinol. Proc Natl Acad Sci USA 102: 4134-4139. 
(c) (P) This work is licensed under Creative Submission Link: https://biomedres.us/submit-manuscript.php

AIOMEDICAL
RESEARCHES $\quad \begin{aligned} & \text { Assets of Publishing with us } \\ & \text { - Immediate, unrestricted online access }\end{aligned}$

